Research Article

\title{
Status of safe drinking water in the rural areas of a health unit district, Tamil Nadu, India
}

\author{
Renuka Venkatesh*, Satheesh B. C., P. Sivaprakasam, Mahendran C., Prasan Norman, \\ J. Robinson, K. R. Pandyan
}

Department of Community Medicine, Meenakshi Medical College and Research Institute, Kanchipuram, Tamil Nadu, India

Received: 24 February 2016

Revised: 08 March 2016

Accepted: 06 April 2016

*Correspondence:

Dr. Renuka Venkatesh,

E-mail: renu_70s@yahoo.co.in

Copyright: (c) the author(s), publisher and licensee Medip Academy. This is an open-access article distributed under the terms of the Creative Commons Attribution Non-Commercial License, which permits unrestricted non-commercial use, distribution, and reproduction in any medium, provided the original work is properly cited.

\section{ABSTRACT}

Background: In spite of numerous on-going efforts by the government of India to improve the availability and accessibility of water supply, provision of water supply still continues to be a challenge especially in rural areas. The present study intended to determine the availability and accessibility of drinking water supply system in the study population and also attempted to assess the knowledge and practice of the households about use of safe water.

Methods: A cross-sectional study was carried out in Cheyyar taluk which comes under the Cheyyar health unit district of Tamil Nadu, India. The samples were drawn using the Stratified random sampling technique. From each strata, $20 \%$ of villages were selected randomly and in each village, $10 \%$ of the households were identified as the sampling unit. Thus, the study was carried out in 74 villages and 1515 households.

Results showed that the water supply system was available and accessible to all the villages in the entire study area. The only lacunae observed were that people were not storing, using and purifying water in the sanitary way.

Conclusion: Our study also supports the results of WHO/UNICEF joint monitoring programme for water supply and sanitation (JMP) which shows we have met the millennium development goal (MDG) set for availability and accessibility of water. Next step would be to concentrate on filling the gap in knowledge regarding safe water storage, usage and purification.

Key words: Availability, Accessibility, Drinking water, Rural areas

\section{INTRODUCTION}

Improving access to safe water and sanitation facilities leads to healthier families and communities. The United Nations General Assembly has recognized drinking water and sanitation as a human right. The WHO/UNICEF joint monitoring programme for water supply and sanitation (JMP) monitors progress towards the MDG target to halve, by 2015, the proportion of people without sustainable access to safe drinking water and basic sanitation. The final report in 2015 stated that the world has made a significant progress with $91 \%$ of the global population (6.6 billion) using an improved drinking water source. ${ }^{1}$ It also has brought about issues of regional variation between countries and urban rural disparities. Although access to safe drinking water has increased in recent years, the report stresses the need for more accurate data gathering worldwide focussing on the gaps.

In India, the provision of clean drinking water has been given priority in the Constitution, with Article 47 conferring the duty of providing clean drinking water and improving public health standards to the State. Constant 
efforts have been made in this direction starting from the Bhore committee in 1946 to Accelerated Rural Water Supply Programme (1972), Rajiv Gandhi drinking water mission (1991), and swajaldhara scheme (1999 enpowering and involving local communities in tackling water and sanitation issues).

In 1981, Government of India also launched the international water supply and sanitation decade (81-90) programme with one of the targets being $100 \%$ coverage of rural and urban population with safe drinking water supply facilities. To supplement this effort, Technology Mission for drinking water [TM] was set up in 1986 which was renamed as Rajiv Gandhi National Drinking Water Mission [RGNDWM] in 1991. Again in 1999, the department of drinking water supply was created in the ministry of rural development. ${ }^{2}$ All these initiatives wanted to achieve the target of $100 \%$ coverage with safe drinking water by 2015 . One of the norms was to provide 40 litres of safe drinking water per capita per day, establishing one hand-pump or stand post for every 250 persons and the water source should exist within the habitation / within 1.6 kilometres in the plains and within 100 Metres elevation in the hilly areas. ${ }^{3}$

Despite the national commitment to supply safe drinking water, access to water is difficult especially in rural areas. The National family health survey-III (2005-06) projected that only $25 \%$ of households in India had private water supply facility, $18 \%$ used public water supply and $43 \%$ used tube wells. ${ }^{4}$ The Department of drinking water supply said that the drinking water coverage was $66.4 \%$ in rural areas. ${ }^{5}$ And, the census 2011 reveals only $47 \%$ have house service connections, a good $36 \%$ still have to fetch water located within 500 metres in rural areas. ${ }^{6}$ Also, the report of (2015) joint monitoring committee now states that India has achieved the target of MDG. ${ }^{1}$

There appears to be little consensus in the data reported by various departments. Also, the baseline survey on water and sanitation carried out in the entire country by the Ministry of Drinking water and sanitation in 2012, showed that there was paucity of information reported from Tiruvanamalai district in Tamilnadu state. ${ }^{7}$ A proportion of this district being the field practice area of the Medical Institution, and based on the observations made during the field visits to the villages, the present study was carried out to describe the current status of safe drinking water in the rural areas of Cheyyar health unit district with the following objectives:

- To determine the availability and accessibility of drinking water supply system in the study population.

- To assess knowledge and practice of the households about use of safe water.

\section{METHODS}

This cross-sectional study was carried out in one of the health unit districts (Cheyyar) of Tamil Nadu state, India. The study was carried out in 2013 for a period of four months. The health unit district is divided into 3 talukas (a taluka is a subdivision of a district- a group of several villages organized for revenue purposes in India) namely Arani, Cheyyar and vandavasi. The study was conducted in one (Cheyyar) taluk (population of 2,88,004 distributed in 374 villages) which comprised of three blocks-vembakkam, Anakkavur and Cheyyar, with vembakkam having 153 Villages, Cheyyar having 117 villages and Anakkavur having 104 villages.

Stratified random sampling technique was followed to draw samples from all the villages in the three blocks. All the villages in the three blocks together were stratified based on their population size into ten strata. From each strata, $20 \%$ of villages were selected randomly, that is, a total of 74 villages were selected. This resulted in selection of 31 villages from vembakkam, 22 villages from Anakkavur and 21 villages from Cheyyar. In each village, $10 \%$ of the households were again selected at random by simple random sampling method with the individual household being the sampling unit. A total of 1515 households were identified finally. Data collection was done both by field observation method, check list and also by using a pre tested questionnaire. In each village, a prior consent was taken from the village leaders after having a preliminary meeting with them and explaining them the purpose of the study.

An inventory of all the community water facilities, information about their functional status and maintenance was taken in all the identified 74 villages. The check list included questions on source of water supply to the village, location of water source, opinion about the water supply, water purification practices which was collected by interacting with the village leaders and villagers. The information about knowledge and practice regarding use of safe water was collected using structured questionnaire. Estimation of residual chlorine was done using Goodmans Chloroscope provided by NEERI (National Environmental Engineering Research Institute), Government of India. It is an ideal apparatus, simple, sturdy, compact, portable and suitable for the field.

The results were analysed using the following criteria:

Availability of water was defined as presence or absence of a water supply delivery system in the village. Access to safe drinking-water was measured as the proportion of population using an improved drinking-water source. ${ }^{8}$

Sanitary storage/usage: Storage of water was said to be sanitary when the container used to store water was covered. Usage was sanitary when the individual's bare hands did not come in contact with water during use. 
Health education regarding water and sanitation was given to the villagers at the end of the study.

\section{RESULTS}

Of the 74 villages selected for the purpose of our study, 31 villages were from vembakkam block, 22 villages were from Anakkavur block and 21 villages were from Cheyyar block.

\section{Availability of water supply at village level}

In majority $40(54 \%)$ of the villages, the main source of water supply was from underground water (Table 1).

Overhead tanks were constructed in all the study villages to store the water coming from the source. At least one overhead tank was present in $39(52.7 \%)$ villages and 14 $(18.9 \%)$ of the villages had more than three overhead tanks in the entire study area.

Table 1: Availability of drinking water supply system in the study population.

\begin{tabular}{|c|c|c|c|c|}
\hline Particulars & $\begin{array}{l}\text { Cheyyar } \\
\text { taluk (Total) }\end{array}$ & $\begin{array}{l}\text { Vembakkam } \\
(\%) \\
\text { Block }\end{array}$ & $\begin{array}{l}\text { Anakkavur (\%) } \\
\text { Block }\end{array}$ & $\begin{array}{l}\text { Cheyyar (\%) } \\
\text { Block }\end{array}$ \\
\hline Number of study villages & $\mathrm{N}=74(\%)$ & $\mathrm{N}=31(\%)$ & $\mathrm{N}=22(\%)$ & $\mathrm{N}=21(\%)$ \\
\hline $\begin{array}{l}\text { Source of water supply to the village } \\
\text { - } \quad \text { River } \\
\text { - } \quad \text { Lake } \\
\text { - } \quad \text { Under ground water }\end{array}$ & $\begin{array}{l}27(36.5) \\
7(9.5) \\
40(54)\end{array}$ & $\begin{array}{l}9(29) \\
1(3.2) \\
21(67.7)\end{array}$ & $\begin{array}{l}10(45.5) \\
2(9) \\
10(45.5)\end{array}$ & $\begin{array}{l}8(38.1) \\
4(19) \\
9(42.9))\end{array}$ \\
\hline $\begin{array}{l}\text { Method of drawing water from source } \\
\text { - Infiltrationgalleries(bore wells) } \\
\text { - } \quad \text { From river/ lake, Bore wells linked } \\
\text { to Overhead tank } \\
\text { - } \quad \begin{array}{l}\text { Open wells linked to Overhead } \\
\text { tank }\end{array}\end{array}$ & $\begin{array}{l}34(45.9) \\
27(36.5) \\
13(17.5)\end{array}$ & $\begin{array}{l}10(32.2) \\
16(51.6) \\
5(16.1)\end{array}$ & $\begin{array}{l}12(54.5) \\
4(18.2) \\
6(27.3)\end{array}$ & $\begin{array}{l}12(57.1) \\
7(33.3) \\
2(9.5)\end{array}$ \\
\hline 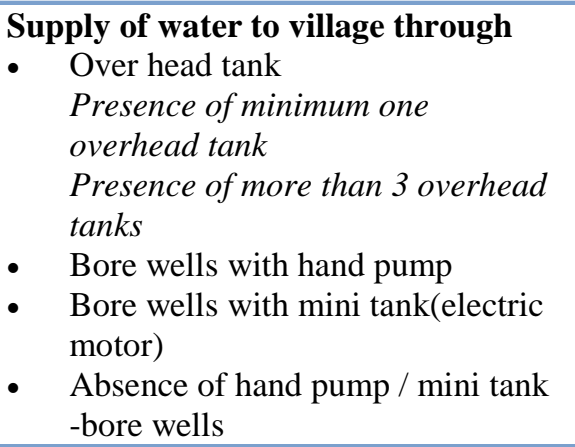 & $\begin{array}{l}14(19) \\
64(86.5 \%) \\
40(54 \%) \\
7(9.4)\end{array}$ & $\begin{array}{l}20(64.5) \\
3(9.7) \\
26(83.9) \\
15(48.4) \\
4(12.9)\end{array}$ & $\begin{array}{l}8(36.4) \\
6(27.3) \\
20(90.9) \\
17(77.3) \\
1(4.5)\end{array}$ & $\begin{array}{l}11(52.4) \\
5(23.8) \\
18(85.7) \\
8(38.1) \\
2(9.5)\end{array}$ \\
\hline $\begin{array}{l}\text { Functional status } \\
\text { - Overhead tank functioning } \\
\text { - } \quad \text { Absence of a single functioning } \\
\text { bore wells }\end{array}$ & $\begin{array}{l}74(100) \\
9(12.2)\end{array}$ & $31(100)$ & $22(100)$ & $\begin{array}{l}21(100) \\
5(23.8)\end{array}$ \\
\hline
\end{tabular}

The source of water supply to these overhead tanks depended on their proximity to the two rivers namely, Cheyyar and Palar Rivers. The source of water to 9 (29\%) villages in vembakkam, $10(45.4 \%)$ villages in Anakkavur and $8(38 \%)$ villages in cheyyar was through infiltration galleries (bore wells) dug in these two dry rivers. This water was pumped either directly to an overhead tank or through a pumping station to the surrounding villages.

On the other hand, the villages which were situated away from the river bed either got their water from the lake or underground water (bore well/open well). Seven (9.5\%) villages from the entire study area got water from bore wells dug in the lake bed, 27 (36.5\%) of them from bore wells directly linked to overhead tank and $13(17.6 \%)$ from deep open wells linked to the overhead tank (Table 1).

All the overhead tanks were covered with lid, each tank varied in its capacity depending on the population to be served. Almost all the overhead tanks were provided with taps below and all the villages had water supply through the street taps with adequate tap points.

With regard to chlorination of the overhead tanks, chlorine tablets provided by the Primary health centres were used for the purpose, where in 1 tablet equals 
20 grams with instruction being given to use 1 tablet for 15,000 Litres. In some villages, 50 gram tablets was also used ( 1 tablet for 15000 Litres).The instruction given was to put the chlorine tablets directly into the tank. However, only $6(8 \%)$ villages in the entire study area did chlorination weekly, $47(64 \%)$ villages did it once in 15 days and $21(28 \%)$ villages once monthly. Every village had an operator to do the chlorination which was supervised either by the village secretary or the Panchayat President. Estimation of residual chlorine was done in all the 74 villages both at the starting point of supply and end point, using the Goodmans Chloroscope to give a crude estimate of the residual chlorine in all villages. Surprisingly, all the 74 villages had residual chlorine of less than $0.1 \mathrm{ppm}$ at the starting point itself.

In case of power crisis, people used the bore well (with hand pump or with mini tank) water provided in the villages mainly as an alternative source. Cleaning of the overhead tank was done with bleaching powder monthly in $54(73 \%)$ villages and once in 15 days in $20(27 \%)$ villages.

Water was also supplied through bore wells with hand pump in 64 villages along with bore wells with mini tank (fitted with electric motor pump) in 40 villages. Of these, not a single bore well (both hand pump and mini tank) was functioning in $9(12.2 \%)$ villages

In 4 villages, ponds were used by the villagers for drinking without purification in spite of the presence of water supply system. In one village, pond was the main and only source of water supply used by all the villages in spite of the pond being unclean with water plants (lotuses) in plenty in the pond. That village is provided with two overhead tanks, the source of water to this tank being river water and bore well. People were refusing to use it because of the dual source of supply to the overhead tank-they found the taste of water not satisfactory.

\section{Accessibility of water at household level}

Of the 1515 houses surveyed from 74 villages, 705 $(46.5 \%)$ houses were terraced, $538(35.5 \%)$ were tiled and $272(18 \%)$ were thatched. Most $1227(81 \%)$ of the houses were on the streets (main village) and $102(6.7 \%)$ which comprised mainly of the lower caste were staying in the outskirts of the villages. The average family size was 4.36.The literacy status (as per census of India 2011 definition) comprised of $64.7 \%$ literates and $35.3 \%$ illiterates. The proportion of illiterates was higher when compared to the entire state of Tamilnadu (19.7\%) as per census $2011 .^{9}$

A majority $95.3 \%$ of households in all the three blocks availed water from the overhead tank in the villages. Of these, $1016(70.4 \%)$ of them fetched water from the street taps, $240(16.6 \%)$ walked to the overhead tank to collect water directly from the tap below it and only $188(13 \%)$ had individual taps in their houses (Table 2).

This was irrespective of the location of the house within the village or outskirts as $96.3 \%$ of the outskirt households also used street supply from overhead tank. The distance for accessing the water source was an average of 100metres for all the households.

The use of bore well with hand pump for drinking purposes was less than $1 \%$ in all the three blocks. In Vembakkam block, $37(6.4 \%)$ used pond water and 7 (1.2\%) used water from an open well for drinking purposes.

With regard to their opinion about the public water system, $98.3 \%$ of the households perceived the overhead tank water to be a safe source,98.4\% said water was colourless, palatable and of acceptable odour (99\%).

When asked about the regularity of water, $83.5 \%$ said there was interrupted water supply with water coming on alternate days $(87.7 \%)$. In $57 \%$ of the households, the storage of water was not sanitary and 54\% of the households the usage was not sanitary (Table 2).

When asked about source of water for other purposes (other than drinking), $923(60.9 \%)$ used water from overhead tank and $318(21 \%)$ used bore well water (Table 2). This indicates wastage of drinking water sources as the water from the overhead tank was wasted for activities other than drinking. Only in Vembakkam block, $11.9 \%$ of households were also using pond water for other purposes.

Although 64 villages were provided with bore wells fitted with hand pump and 40 villages with bore wells with mini tank, only $29 \%$ used the bore well water for all purposes.

\section{Knowledge and Practice of households about use of safe water}

Majority $(87.7 \%)$ of the households said diseases can be transmitted through water (Table 3 ). When asked to name the diseases transmitted through water, multiple responses were elicited and 703 (46.4\%) did not respond. They preferred not to respond probably fearing, if their answer to such a common question would be wrong. The most common disease named was fever 496 (32.7\%).

The knowledge with respect to the above aspects was similar in all the three blocks. Only $36.4 \%$ had the knowledge that boiling and water filter can be used to purify water. When asked for purification method they used, majority 1069 (70.6\%) answered that they do not use any method. 
Table 2: accessibility of drinking water supply system in the study population.

\begin{tabular}{|lllll|}
\hline Particulars & $\begin{array}{l}\text { Cheyyar taluk } \\
\text { (Total) }\end{array}$ & $\begin{array}{l}\text { Vembakkam } \\
\text { Block }\end{array}$ & $\begin{array}{l}\text { Anakkavur } \\
\text { Block }\end{array}$ & $\begin{array}{l}\text { Cheyyar } \\
\text { Block }\end{array}$ \\
\hline No. of households & $1515(\%)$ & $582(\%)$ & $574(\%)$ & $359(\%)$ \\
\hline $\begin{array}{l}\text { Use of water for drinking } \\
\text { Overhead tank } \\
\text { Bore well with hand pump/mini tank }\end{array}$ & $\begin{array}{l}1444(95.3) \\
11(0.7)\end{array}$ & $\begin{array}{l}533(91.5) \\
5(0.9)\end{array}$ & $\begin{array}{l}565(98.4) \\
5(0.9)\end{array}$ & $\begin{array}{l}346(96.4) \\
1(0.3)\end{array}$ \\
\hline $\begin{array}{l}\text { Collection of water from overhead tank } \\
\text { from streets }\end{array}$ & $1016(70.4)$ & $354(66.4)$ & $425(75.2)$ & $237(68.5)$ \\
Having tap within house premises & $188(13)$ & $84(15.8)$ & $56(9.9)$ & $48(13.9)$ \\
\hline $\begin{array}{l}\text { Storage of water } \\
\text { not sanitary }\end{array}$ & $864(57)$ & $346(59.5)$ & $328(57.1)$ & $190(52.9)$ \\
\hline $\begin{array}{l}\text { Usage of water } \\
\text { not sanitary }\end{array}$ & $818(54)$ & $387(66.5)$ & $243(16)$ & $188(52.4)$ \\
\hline $\begin{array}{l}\text { Source of water for other purposes } \\
\text { Bore well }\end{array}$ & $318(21)$ & $112(19.2)$ & $116(20.2)$ & $90(25.1)$ \\
Overhead tank & $923(60.9)$ & $353(60.7)$ & $375(65.3)$ & $195(54.3)$ \\
\hline
\end{tabular}

Table 3: Knowledge and practice of households about use of safe water in the study population.

\begin{tabular}{|ll|}
\hline $\begin{array}{l}\text { Information about knowledge and } \\
\text { practice }\end{array}$ & $\begin{array}{l}\text { Cheyyar } \\
\text { taluk }(\%)\end{array}$ \\
\hline $\begin{array}{l}\text { Transmission of disease through water } \\
\text { Yes }\end{array}$ & $1328(87.7)$ \\
No & $126(8.3)$ \\
Do not know & $61(4)$ \\
\hline Naming the diseases transmitted & \\
through water & $496(32.7)$ \\
Fever & $113(7.5)$ \\
Diarrhoea & $75(4.5)$ \\
Cholera & $703(46.4)$ \\
Did not know & \\
\hline Cause for typhoid & $621(41)$ \\
Water & $670(44.2)$ \\
Did not answer & \\
\hline Cause for diarrhoea & $540(35.6)$ \\
Water & $209(13.8)$ \\
food & $608(40.1)$ \\
\hline Did not answer & \\
\hline Cause for jaundice & $532(35.1)$ \\
Water & $669(44.2)$ \\
\hline Did not answer & $1069(70.6)$ \\
\hline Knowledge on methods of water purification \\
Boiling & $469(31)$ \\
Boiling, water filter & $551(36.4)$ \\
Boiling, water filter and straining by cloth & $257(17)$ \\
Do not know & $23(1.5)$ \\
\hline Purification method used & $96(6.3)$ \\
No method used & 1515 \\
\hline Boiling & \\
Water filter & \\
\hline Total number of households & \\
\hline
\end{tabular}

\section{DISCUSSION}

Our observations revealed that the water supply system was both available and accessible to all the households in the 74 villages. These findings are in line with the final report of the Joint monitoring programme (2015) and far better than that reported by census 2011, Ministry. ${ }^{1,5,6}$ The availability of water in all the villages was from underground source either from river or bores dug into river bed or lake bed.

Regarding chlorination, the instruction as to how often to chlorinate and contact time to be allowed, was not clearly given in all the 74 villages. This resulted in low level of residual chlorine in the water. Though all the villages used the prescribed adequate number of chlorine tablets, the frequency of chlorination was neither adequate nor contact time for chlorination observed. As the water in the overhead tank lasted for three to four days in all the villages, chlorination also was essential every time water was pumped into the tank which was not the situation in all the 74 villages. It was also ascertained that water was not subjected to any periodical water quality checks-both physical, chemical and biological testing, right from the inception of the water supply system in all the villages.

Available water was also accessible to all the people in 74 villages. This is in contrast to the census 2011 which revealed $47 \%$ have the source of water within the premises, $36 \%$ still have to fetch water located within 500 metres. $^{6}$ More number of households (28\%) had individual taps in their premises as shown by the National family health survey-III (2005-06). ${ }^{4}$ Our findings are similar to the study by Kirti Deshpande in a village in Ujjain district (Madhya Pradesh) - 84\% did not have access to water within household premises and $55 \%$ had access to water source at a distance of more than 50 metres. ${ }^{10}$ Harshal et al in his study in rural areas of Pune, Maharashtra, India noted that all the households had 
piped water supply with $43.33 \%$ having tap facility inside the house and $56.67 \%$ outside the house. ${ }^{11}$

Regarding use of bore well water, the NFHS-III (200506) showed that $43 \%$ used tube wells The reasons quoted for use in the present study were availability, easy to use, nearby, used when no electricity and majority said when water from overhead tank was not enough. The remaining $71 \%$ who did not use bore well said it was muddy, impure, salty, not good, not needed and majority said bore well was under repair.

An important observation was none of the households surveyed, purchased mineral water for drinking purpose. This is in contrast to our observation in rural areas of Tamilnadu, that majority of the people used Mineral water because of their easy availability and affordability. Our findings reveal the attitude of the community in considering the water from the overhead tank as a safe source.

Regarding purification of water before use, our findings were similar to the NFHS-III survey (2005-06) where $33 \%$ of the households treat their drinking water to improve its potablity. ${ }^{4}$

The limitation of the present study was that, the water in all the 74 villages could not be subjected to quality testing for chemical and biological standards due to monetary reasons. Further, the results of the present study can be generalized to the entire rural health unit district of Cheyyar due to similar geographical distribution and socio economic characteristics.

To summarize, the water supply system was available and accessible to all the villages in the entire taluk. This is far better than that reported by Census, Ministry of rural development and the NFHS-3 survey. Though the supply was not continuous, at least interrupted water supply system has been established. In case of power crisis, alternative supply also was made available. Bore wells though present were either functioning but not used due to various reasons and the non- functioning bore wells were left unattended People were also using pond water in few villages. The only lacunae was that people were not storing, using and purifying water in the sanitary way due to gaps in the knowledge. As a result, the water borne diseases will continue to be prevalent which has an indirect effect on the nutrition and growth of children thereby influencing their morbidity and mortality.

\section{CONCLUSION}

Though water supply was available and accessible to all villages, the water was never subjected for quality standard testing since its establishment. Chlorination of the overhead tanks was not satisfactory. It was not done regularly and in a scientific way. There is still gap in the knowledge regarding safe water storage, usage and purification. Hence, suitable programmes to impart health education needs to be planned to raise the awareness of the communities.
Funding: Maher university (Meenakshi academy of higher education and research) deemed university, Chennai, Tamilnadu,India

Conflict of interest: None declared

Ethical approval: Not required

\section{REFERENCES}

1. WHO/UNICEF Joint Monitoring Programme for Water Supply and Sanitation. 2015. Meeting the MDG drinking water and sanitation target: a midterm assessment of progress. World Health Organization, Geneva and United Nations Children's Fund, New York.

2. Khurana I, Sen R. Drinking water quality in rural India: Issues and approaches. 2005. Background paper by Water Aid retrieved at www.wateraid.org.

3. Public Health Engineering department, Government of India. Background of water supply and sanitation programme, retrieved at http://megphed.gov.in/ dept/ backgrd.pdf

4. National Family Health survey III (2005-06). Environmental health. Retrieved at http//www.nfhsindia.org/NFHS-3\%20DATA/

Afterdiss/ PPT/ NFHS-3\%20Environmental\%20 Health.ppt

5. Department of Drinking Water Supply, Union Ministry of Rural Development. 2009. Drinking water coverage status of habitations. Retrieved at www.ddws.nic.in/ OnlineMonitoring/ indexframeset.htm

6. Census 2011, Government of India. 2012. Press Note on Release of Data on Houses, Household Amenities and Assets, Retrieved at http://censusindia.gov.in/ 2011census/ hlo/ Data_sheet/ India/HLO_Press_Release.pdf

7. Ministry of drinking water and sanitation retrieved at $\mathrm{ht} / / \mathrm{www}$.mdws.gov.in

8. WHO/UNICEF Joint Monitoring Programme for Water Supply and Sanitation. 2004. Meeting the MDG drinking water and sanitation target: a midterm assessment of progress. World Health Organization, Geneva and United Nations Children's Fund, New York.

9. Tamil Nadu state Census 2011. Available at http://www.census2011.co.in/ census/ state/ tamil+nadu.html.

10. Deshpande K, Kakkar R, Diwan V. Access to quantity and quality of water: problems perceived by residents of village Palwa in Ujjain district. Indian J Community Medicine. 2007;32:295-6.

11. Pandve HD, Fernandez K, Chawla PS, Singru SA. Assessment of Environmental sanitation in rural areas of Pune, Maharashtra. Indian J of Occupational and Environmental Medicine. 2012;16: 90.

Cite this article as: Venkatesh $\mathrm{R}$, Satheesh $\mathrm{BC}$, Sivaprakasam P, Mahendran C, Norman P, Robinson J, Pandyan KR. Status of safe drinking water in the rural areas of a health unit district, Tamil Nadu, India. Int J Community Med Public Health. 2016;3: 1123-8. 